\title{
PENGARUH PROFESIONALISME, PENGETAHUAN MENDETEKSI KEKELIRUAN, DAN ETIKA PROFESI TERHADAP PERTIMBANGAN TINGKAT MATERIALITAS AKUNTAN PUBLIK (Studi Kasus pada KAP di Wilayah Jakarta Barat)
}

\author{
Adolpino Nainggolan. SE, M.Ak \\ Rizki Amalia
}

\author{
Fakultas Ekonomi Program Akuntansi \\ Universitas Satya Negara Indonesia
}

\begin{abstract}
Abstrak
Tujuan penelitian ini adalah untuk memperoleh bukti empiris tentang pengaruh profesionalisme, pengetahuan mendeteksi kekeliruan, dan etika profesi terhadap pertimbangan tingkat materialitas. Populasi dalam penelitian ini adalah auditor, sampel yang digunakan sebanyak 46 responden dari 10 Kantor Akuntan Publik di wilayah Jakarta Barat. Data dianalisis menggunakan regresi berganda.
\end{abstract}

Hasil penelitian menunjukkan bahwa profesionalisme, pengetahuan mendeteksi kekeliruan, dan etika profesi memiliki pengaruh yang signifikan terhadap pertimbangan tingkat materialitas. Secara parsial, profesionalisme dan etika profesi memiliki pengaruh yang signifikan terhadap pertimbangan tingkat materialitas.

Kata Kunci: Profesionalisme, Pengetahuan mendeteksi kekeliruan, dan Etika profesi terhadap Pertimbangan tingkat materialitas.

\section{PENDAHULUAN}

Auditor yang independen dalam melaksanakan audit atas laporan keuangan tidak hanya berpaku pada satu kepentingan klien saja, melainkan untuk kepentingan banyak pihak diantaranya para pemegang saham dan para pemakai informasi laporan keuangan tersebut. Untuk dapat mempertahankan kepercayaan dari klien dan dari pihak berkepentingan lainnya, auditor dituntut untuk mempunyai kompetensi diri yang memadai. Statement of Financial Accounting Concept (SFAC) No.2 menyatakan bahwa relevansi reliabilitas merupakan dua kualitas umum yang memuat informasi akuntansi yang berguna untuk membuat suatu keputusan. Untuk dapat mencapai kualitas relevan dan reliabel maka laporan keuangan perlu di audit oleh auditor untuk memberikan jaminan kepada pemakai bahwa laporan keuangan tersebut telah disusun sesuai dengan kriteria yang ditetapkan, yaitu Standar Akuntansi Keuangan (SAK) yang berlaku di Indonesia.

Dengan demikian auditor harus meningkatkan kinerjanya agar dapat menghasilkan suatu laporan audit yang kompeten bagi pihak yang berkepentingan. Guna peningkatan kinerja, auditor dituntut untuk memiliki profesionalisme dalam melakukan audit atas laporan keuangan. Menurut Hall R dalam Reni Yendrawati (2008) menjelaskan seseorang yang profesional dalam profesi akuntan dicerminkan dengan lima dimensi profesionalisme, yaitu : (1) pengabdian pada profesi, (2) kewajiban sosial, (3) kemandirian, (4) keyakinan terhadap peraturan profesi, dan (5) hubungan dengan sesama profesi.

Setiap akuntan publik juga diharapkan memiliki pengetahuan yang memadai dalam profesinya untuk mendukung pekerjaannya dalam melakukan setiap pemeriksaan. Akuntan yang lebih berpengalaman akan bertambah pengetahuannya dalam melakukan proses audit khususnya dalam mendeteksi kekeliruan. Menurut SAS 99 (AU 316) kekeliruan (error) adalah salah saji dalam laporan keuangan yang tidak disengaja. Pengetahuan akuntan publik dalam mendeteksi 
kekeliruan laporan keuangan dapat diperoleh dari berbagai pelatihan formal maupun dari pengalaman khusus.

Selain profesionalisme dan pengetahuan mendeteksi kekeliruan, seorang akuntan publik juga harus memegang teguh etika profesi yang sudah ditetapkan oleh Ikatan Akuntan Indonesia (IAI), agar situasi persaingan tidak sehat dapat dihindarkan. Di Indonesia, etika akuntan menjadi isu yang sangat menarik. Hal ini seiring dengan terjadinya beberapa pelanggaran etika yang dilakukan oleh akuntan, baik akuntan independen, akuntan intern perusahaan maupun akuntan pemerintah. Menurut IAI, kode etik adalah aturan perilaku seorang akuntan dalam memenuhi tanggung jawab profesionalnya. Kode etik seorang akuntan meliputi, antara lain prinsip etika akuntan, aturan etika akuntan, dan interpretasi aturan etika akuntan.

Pertimbangan dalam menetapkan tingkat materialitas sangat tergantung pada persepsi auditor tentang kebutuhan atas informasi yang terdapat pada informasi yang diberikan manajemen maupun didapat oleh auditor dalam proses audit, sehingga tingkat materialitas suatu laporan keuangan tidak akan sama tergantung pada ukuran laporan keuangan tersebut.

\section{Berdasarkan uraian diatas, maka peneliti tertarik untuk mengambil judul "PENGARUH PROFESIONALISME, PENGETAHUAN MENDETEKSI KEKELIRUAN, DAN ETIKA PROFESI PADA PERTIMBANGAN TINGKAT MATERIALITAS AKUNTAN PUBLIK".}

Atas dasar variabel-variabel tersebut diatas memberikan pendapat yang berbeda-beda tentang faktor yang mempengaruhi pertimbangan tingkat materialitas akuntan publik. Maka penelitian ini dimaksudkan untuk menguji kembali hubungan profesionalisme, pengetahuan mendeteksi kekeliruan dan etika profesi terhadap pertimbangan tingkat materialitas akuntan publik.

Permasalahan pokok dalam penelitian ini adalah :

1. Apakah profesionalisme berpengaruh terhadap pertimbangan tingkat materialitas akuntan publik?

2. Apakah pengetahuan mendeteksi kekeliruan berpengaruh terhadap pertimbangan tingkat materialitas akuntan publik?

3. Apakah etika profesi berpengaruh terhadap pertimbangan tingkat materialitas akuntan publik?

4. Apakah profesionalisme, pengetahuan mendeteksi kekeliruan, dan etika profesi berpengaruh terhadap pertimbangan tingkat materialitas akuntan publik?

\section{LANDASARAN TEORI}

\subsection{Auditing}

Definisi dari auditing menurut Arens, Elder dan Beasley (2015) dalam Auditing and Assurance Services, Fifteenth Edition adalah pengumpulan dan evaluasi bukti tentang informasi untuk menetukan dan melaporkan derajat kesesuaian antara informasi itu dan kriteria yang telah ditetapkan. Auditing harus dilakukan oleh orang yang kompeten dan independen.

Audit mempunyai sifat analitis, karena akuntan publik memulai pemeriksaannya dari angka-angka dalam laporan keuangan, lalu dicocokkan dengan neraca saldo (trial balance), buku besar (general ledger). Sedangkan accounting mempunyai sifat konstruktif, karena disusun mulai dari bukti-bukti pembukuan, buku harian, buku besar dan sub buku besar, neraca saldo sampai menjadi laporan keuangan. 
Menurut Arens, Elder dan Beasley (2015) dalam Auditing and Assurance Services, Fifteenth Edition, Akuntan publik melakukan tiga jenis utama audit, diantaranya :

1. Audit Operasional,

2. Audit Ketaatan, dan

3. Audit Laporan Keuangan.

\subsection{Pertimbangan Tingkat Materialitas}

Definisi dari materialitas dalam kaitannya dengan akuntansi dan pelaporan audit menurut Arens, Elder dan Beasley (2015) dalam Auditing and Assurance Services, Fifteenth Edition adalah besarnya penghapusan atau salah saji informasi akuntansi yang dengan mempertimbangkan situasinya, menyebabkan pertimbangan seseorang yang bijaksana yang mengandalkan informasi tersebut akan berubah atau terpengaruh oleh penghapusan atau salah saji tersebut.

Penentuan materialitas memerlukan pertimbangan profesional. Auditor diharuskan mengikuti lima langkah yang saling terikat erat dalam menetapkan materialitas, diantaranya sebagai berikut : (1) Menetapkan materialitas untuk laporan keuangan secara keseluruhan; (2) Menentukan materialitas kinerja; (3) Mengestimasi total salah saji dalam segmen; (4) Mengestimasi salah saji gabungan; dan (5) Membandingkan estimasi salah saji gabungan dengan pertimbangan pendahuluan atau yang direvisi tentang materialitas.

Konsep materialitas menyatakan bahwa tidak semua informasi keuangan diperlukan atau tidak semua informasi seharusnya dikomunikasikan. Dalam laporan akuntansi hanya informasi yang material saja yang seharusnya disajikan. Informasi yang tidak material sebaiknya diabaikan atau dihilangkan. Pertimbangan auditor mengenai materialitas merupakan pertimbangan profesional dan dipengaruhi oleh persepsi auditor atas kebutuhan orang yang memiliki pengetahuan memadai dan yang akan meletakkan kepercayaan terhadap laporan keuangan (Ikatan Akuntan Indonesia, 2001).

\subsection{Profesionalisme Auditor}

Dalam pengertian umum, seseorang dikatakan profesional jika memenuhi tiga kriteria, yaitu mempunyai keahlian untuk melaksanakan tugas sesuai dengan bidangnya, melaksanakan suatu tugas atau profesi dengan menetapkan standar baku di bidang profesi yang bersangkutan dan menjalankan tugas profesinya dengan mematuhi etika profesi yang telah ditetapkan. Profesi dan profesionalisme dapat dibedakan secara konseptual. Profesi merupakan jenis pekerjaan yang memenuhi beberapa kriteria, sedangkan profesionalisme adalah suatu atribut individual yang penting tanpa melihat suatu profesi atau tidak (Lekatompessy, 2003 dalam Herawaty dan Susanto, 2009: 3). Seorang akuntan publik yang profesional harus memenuhi tanggung jawabnya terhadap masyarakat, klien termasuk rekan seprofesi untuk berperilaku semestinya. Ia juga harus memenuhi dan mematuhi standar-standar kode etik yang telah ditetapkan oleh IAI (Ikatan Akuntan Indonesia). Menurut Hall R dalam Reni Yendrawati (2008) menjelaskan seseorang yang profesional dalam profesi akuntan dicerminkan dengan lima dimensi profesionalisme, yaitu : (1) pengabdian pada profesi, (2) kewajiban sosial, (3) kemandirian, (4) keyakinan terhadap peraturan profesi, dan (5) hubungan dengan sesama profesi.

\subsection{Pengetahuan Mendeteksi Kekeliruan}

Pengetahuan akuntan publik bisa diperoleh dari berbagai pelatihan formal maupun dari pengalaman khusus, bisa berupa seminar, lokakarya serta pengarahan dari auditor senior kepada auditor junior. Pengetahuan juga dapat diperoleh dari banyaknya frekuensi seorang auditor 
melaksanakan pekerjaan dalam proses audit laporan keuangan suatu perusahaan. Seseorang yang melakukan pekerjaan sesuai dengan pengetahuan yang dimilikinya tentu akan memberikan hasil yang lebih baik daripada mereka yang kurang memiliki pengetahuan yang memadai akan tugasnya (Herawaty dan Susanto, 2009: 16). Pengetahuan seorang akuntan publik digunakan sebagai salah satu kunci keefektifan kerja.

Pengertian kekeliruan menurut Ikatan Akuntan Indonesia (IAI) dalam Standar Profesional Akuntan Publik (SPAP) paragraf 6, dinyatakan bahwa kekeliruan (error) berarti salah saji (misstatement) atau hilangnya jumlah atau pengungkapan dalam laporan keuangan yang tidak disengaja. Kekeliruan dapat berupa (1) Kekeliruan dalam pengumpulan atau pengolahan data yang menjadi sumber penyusunan laporan keuangan; (2) Estimasi akuntansi yang tidak masuk akal yang timbul dari kecerobohan atau salah tafsir fakta; (3) Kekeliruan dalam penerapan prinsip akuntansi yang berkaitan dengan jumlah, klasifikasi dan cara penyajian atau pengungkapan.

Menurut pendapat Erick (2005: 45) kegagalan dalam mendeteksi kekeliruan yang material akan mempengaruhi kesimpulan dari pengguna laporan keuangan. Faktor utama yang menjadikan perbedaan antara kesalahan dengan kecurangan adalah tindakan yang mendasarinya yang berakibat terjadinya salah saji (misstatement) dalam laporan keuangan. Untuk membedakan salah saji tersebut disengaja atau tidak disengaja, dalam praktiknya sangat sulit untuk dibuktikan, terutama yang berkaitan dengan estimasi akuntansi dan penerapan prinsip akuntansi.

\subsection{Etika Profesi}

Etika profesional bagi praktik akuntan di Indonesia disebut dengan istilah kode etik dan dikeluarkan oleh Ikatan Akuntan Indonesia (IAI), sebagai organisasi profesi akuntan. Kode etik ini mengikat para anggota IAI di satu sisi dan dapat dipergunakan oleh akuntan lainnya yang bukan atau belum menjadi anggota IAI di sisi lainnya. Kode Etik Profesi Akuntan Publik adalah aturan etika yang harus diterapkan oleh anggota Institut Akuntan Publik Indonesia atau IAPI (sebelumnya Ikatan Akuntan Indonesia-Kompartemen Akuntan Publik atau IAI-KAP) dan staf profesional (baik yang anggota IAPI maupun yang bukan anggota IAPI) yang bekerja pada satu Kantor Akuntan Publik.

Menurut Arens, Elder dan Beasley (2015: 99) dalam Auditing and Assurance Services, Fifteenth Edition, terdapat 6 prinsip-prinsip dasar etis seorang auditor, diantaranya:

1. Tanggung Jawab

2. Kepentingan Publik

3. Integritas

4. Objektivitas dan Independensi

5. Keseksamaan

6. Ruang Lingkup dan Sifat Jasa

\section{METODE PENELITIAN}

\subsection{Jenis Data}

Dalam penelitian ini peneliti menggunakan data primer untuk mengukur variabel independen (profesionalisme, pengetahuan mendeteksi kekeliruan, dan etika profesi) dan variabel dependen (pertimbangan tingkat materialitas) dengan pemahaman sistem informasi sebagai variabel independen yang diambil dari individu atau perseorangan, seperti hasil wawancara atau hasil pengisian kuisioner.

\subsection{Populasi dan Sampel Penelitian}


Populasi dalam penelitian ini adalah auditor yang bekerja pada Kantor Akuntan Publik yang berada di wilayah Jakarta Barat yang terdaftar pada Direktori IAPI. Teknik pengambilan sampel dalam penelitian ini menggunakan metode purposive sampling, hal ini dilakukan agar data yang diperoleh dengan tujuan penelitian dan relative dapat dibandingkan dengan hasil penelitian sebelumnya. Berdasarkan metode tersebut maka kriteria penentuan sampel yang digunakan dalam penelitian ini adalah sebagai berikut :

1. Auditor telah memiliki pengalaman minimal 3 (tiga) tahun, hal ini dilakukan karena auditor tersebut telah beradaptasi dengan lingkungan kerjanya.

2. Auditor yang memiliki jenjang pendidikan minimal S1 telah mengetahui bagaimana proses audit suatu laporan keuangan.

\subsection{Desain Penelitian}

Desain penelitian yang digunakan dalam penelitian ini adalah penelitian kausal, yaitu penelitian yang bertujuan untuk mengetahui kemungkinan adanya hubungan sebab akibat dengan cara tertentu berdasar atas pengamatan terhadap akibat yang ada, kemudian mencari kembali faktor yang diduga menjadi penyebabnya, melalui pengumpulan data dengan melakukan perbandingan diantara data yang terkumpul/diteliti (Sumarni dan Wahyuni, 2006: $53)$.

\subsection{Variabel Penelitian}

Dalam penelitian ini penulis menggunakan 2 (dua) variabel yang akan diteliti, yaitu :1) Variabel Bebas (Independent Variabel), variabel bebas merupakan variabel yang mempengaruhi atau yang menjadi sebab perubahannya atau timbulnya variabel dependen (terikat). Dalam penelitian ini yang menjadi variabel " $X$ " adalah sebagai berikut : Profesionalisme $\left(\mathrm{X}_{1}\right)$, Pengetahuan Mendeteksi Kekeliruan $\left(\mathrm{X}_{2}\right)$, dan Etika Profesi $\left(\mathrm{X}_{3}\right)$. 2) Variabel Terikat (Dependent Variabel), variabel terikat merupakan variabel yang dipengaruhi atau yang menjadi akibat karena adanya variabel bebas. Dalam penelitian ini yang menjadi variabel "Y" adalah Pertimbangan Tingkat Materialitas.

\subsection{Metode Analisis Data}

\subsubsection{Analisis Deskriptif}

Penggunaan analisa deskriptif dalam penelitian ini ditujukan untuk memberikan penjelasan variabel yang digunakan dalam penelitian yang meliputi variabel dependen (Y) yaitu pertimbangan tingkat materialitas dan varaiabel independen (X) yaitu profesionalisme, pengetahuan mendeteksi kekeliruan dan etika profesi, sehingga akan didapatkan gambar yang lebih jelas tentang variabel yang di teliti.

\subsubsection{Analisis Statistik}

Analisa statistik bertujuan untuk membuktikan kebenaran hipotesis yang diajukan maka digunakan regresi linier berganda. Ada beberapa tahapan yang dilakukan sebelum melakukan uji regresi linier berganda, yaitu diperlukan uji asumsi klasik terlebih dahulu. Ada empat macam uji asumsi klasik antara lain :

\section{Uji Normalitas}

Uji normalitas bertujuan untuk menguji apakah di dalam model regresi, terdapat variabel pengganggu atau residual memiliki distribusi normal. Untuk mendeteksi apakah residual berdistribusi normal atau tidak, dapat dilakukan dengan analisis grafik, yaitu dengan 
melihat grafik histogram yang membandingkan antara data observasi dengan distribusi yang mendekati distribusi normal (Ghozali : 2007).

\section{Uji Multikolinearitas}

Uji multikollinearitas merupakan pengujian yang dilakukan untuk mengetahui apakah model regresi ditemukan adanya korelasi variabel independent. Model Regresi yang baik tidak terjadi kolerasi antar variabel independent. Cara yang digunakan untuk mendeteksi ada atau tidaknya terjadi multikolenearitas yaitu dengan menggunakan VIF (Variabel Inflation Factory).

\section{Uji Autokorelasi}

Uji autokorelasi merupakan pengujian yang dilakukan untuk mengetahui apakah terdapat korelasi error pada periode $t$ dengan error pada periode t-1 atau periode sebelumnya. Jika terjadi korelasi, maka disebut terdapat problem autokorelasi.

\section{Uji Heterokedastisitas}

Uji Heteroskedastisitas Merupakan pengujian yang dilakukan untuk mengetahui apakah dalam model regresi terjadi ketidaksamaan varians dari residual satu pengamatan ke pengamatan lain. Cara yang digunakan untuk mendeteksi ada atau tidaknya heterokedastisitas dapat diketahui dengan melihat ada atau tidaknya heterokedastisitas dapat diketahui dengan melihat ada tidaknya pola tertentu pada grafik scatterplot antara nilai prediksi variabel dependent dengan residualnya.

\subsubsection{Uji Hipotesis}

\section{Uji t (Uji Regresi Parsial)}

Uji $\mathrm{t}$ adalah pengujian yang dilakukan untuk mengetahui pengaruh masing-masing variabel independen terhadap variabel dependen. Uji $\mathrm{T}$ dilakukan dengan membandingkan antara $t_{\text {hitung }}$ dengan $t_{\text {tabel. }}$. Jika $t_{\text {hitung }}>t_{\text {tabel }}$ maka Ho ditolak dan Jika $t_{\text {hitung }}<t_{\text {tabel }}$ maka Ho diterima.

\section{Uji F (Uji Regresi Simultan)}

Uji $\mathrm{F}$ ini digunakan untuk mengetahui ada atau tidaknya pengaruh secara bersamasama (simultan) variabel-variabel independent terhadap variabel dependent. Hasil uji $\mathrm{F}$ pada output SPSS dapat dilihat pada tabel ANOVA, pembuktiannya dilakukan dengan cara membandingkan nilai $f_{\text {hitung }}$ dengan $f_{\text {tabel. }}$. Jika $f_{\text {hitung }}>f_{\text {tabel }}$ maka Ho ditolak dan jika $f_{\text {hitung }}<f_{\text {tabel }}$ maka Ho diterima.

\section{Koefisien Determinasi}

Koefisien determinasi $\left(R^{2}\right)$ bertujuan untuk mengukur seberapa jauh kemampuan model dapat menjelaskan variasi variabel dependent.

\section{Analisis Regresi Linier Berganda}

Analisis dalam penelitian ini dilakukan teknik analisis regresi linear berganda. Analisis dipilih dalam penelitian ini karena memiliki variabel independen lebih dari satu. Pengujian ini dilakukan untuk mengetahui gambaran secara langsung koefisien regresi atau besarnya pengaruh masing-masing variabel independen (bebas) yaitu Profesionalisme $\left(\mathrm{X}_{1}\right)$, Pengetahuan Mendeteksi Kekeliruan $\left(\mathrm{X}_{2}\right)$, Etika Profesi $\left(\mathrm{X}_{3}\right)$ terhadap variabel dependen (terikat) 
Pertimbangan Tingkat Materialitas (Y) menggunakan analisis linear berganda dapat dirumuskan sebagai berikut :

$$
\mathbf{Y}=\alpha+\beta_{1} X_{1}+\beta_{2} X_{2}+\beta_{3} X_{3}+e
$$

\section{HASIL PENELITIAN DAN ANALISA DATA}

\subsection{Uji Normalitas}

\begin{tabular}{|c|c|c|c|c|c|}
\hline & & $\begin{array}{c}\text { X1_Profes } \\
\text { ionalisme }\end{array}$ & $\begin{array}{c}\text { X2_Pengeta } \\
\text { huan_Mend } \\
\text { eteksi_Keke } \\
\text { liruan }\end{array}$ & $\begin{array}{c}\text { X3_Etika_- } \\
\text { Profesi }\end{array}$ & $\begin{array}{l}\text { Y_Pertimb } \\
\text { angan_Tin } \\
\text { gkat_Mate } \\
\text { rialitas }\end{array}$ \\
\hline \multicolumn{2}{|l|}{$\mathrm{N}$} & 46 & 46 & 46 & 46 \\
\hline Normal & Mean & 749,9995 & 950,0004 & 699,9999 & 600,0016 \\
\hline Parameters ${ }^{\mathrm{a}, \mathrm{b}}$ & Std. Deviation & 93,61511 & 158,84354 & 89,99705 & 72,58315 \\
\hline Most & Absolute &, 176 &, 164 & , 155 & 167 \\
\hline Extreme & Positive &, 176 &, 122 & , 155 &, 167 \\
\hline Differences & Negative &,- 096 &,- 164 &,- 122 &,- 120 \\
\hline \multicolumn{2}{|c|}{ Kolmogorov-Smirnov Z } & 1,193 & 1,115 & 1,050 & 1,133 \\
\hline \multicolumn{2}{|c|}{ Asymp. Sig. (2-tailed) } &, 116 &, 166 & 220 & ,153 \\
\hline
\end{tabular}

a. Test distribution is Normal.

b. Calculated from data.

Dari tabel di atas diperoleh hasil Asymp Sig. (2-tailed) untuk variabel Profesionalisme Auditor $\left(\mathrm{X}_{1}\right)=0.116>0.05$, Pengetahuan Mendeteksi Kekeliruan $\left(\mathrm{X}_{2}\right)=0.166>0.05$,Etika Profesi $\left(\mathrm{X}_{3}\right)=0.22>0.05$ dan Pertimbangan Tingkat Materialitas $(\mathrm{Y})=0.153>0.05$, maka dapat disimpulkan data yang diambil dari populasi berdistribusi normal.

\subsection{Uji Multikolinieritas}

\begin{tabular}{|c|c|c|c|}
\hline \multicolumn{4}{|c|}{ Coefficients $^{a}$} \\
\hline \multirow{2}{*}{\multicolumn{2}{|c|}{ Model }} & \multicolumn{2}{|c|}{ Collinearity Statistics } \\
\hline & & Tolerance & VIF \\
\hline \multirow[t]{5}{*}{1} & (Constant) & & \\
\hline & X1_Profesionalisme & ,560 & 1,785 \\
\hline & X2_Pengetahuan_Mendete & 939 & 1,065 \\
\hline & ksi_Kekeliruan & & \\
\hline & X3 Etika Profesi &, 581 & 1,722 \\
\hline
\end{tabular}

a. Dependent Variable: Y_Pertimbangan_Tingkat_Materialitas

Dari tabel di atas dapat diketahui bahwa nilai variance inflation factor (VIF) ketiga variabel lebih kecil dari 10 , dan nilai tolerance ketiga variabel diatas 0.10 sehingga dapat disimpulkan bahwa tidak terjadi multikolinearitas antarvariabel bebas.

\subsection{Uji Autokorelasi}




\begin{tabular}{|l|c|r|l|r|r|}
\hline Model & R & R Square & $\begin{array}{l}\text { Adjusted R } \\
\text { Square }\end{array}$ & $\begin{array}{l}\text { Std. Error of } \\
\text { the Estimate }\end{array}$ & $\begin{array}{l}\text { Durbin- } \\
\text { Watson }\end{array}$ \\
\hline 1 &, $857^{\mathrm{a}}$ &, 735 &, 716 & 38,71208 & 1,425 \\
\hline
\end{tabular}

a. Predictors: (Constant), X3_Etika_Profesi,

X2_Pengetahuan_Mendeteksi_Kekeliruan, X1_Profesionalisme

b. Dependent Variable: Y_Pertimbangan_Tingkat_Materialitas

Dari hasil output di atas didapat nilai DW yang dihasilkan dari model regresi adalah 1.425. Karena nilai DW terletak antara dL dan dU, maka tidak dapat menghasilkan kesimpulan yang pasti.

\subsection{Uji Heterokedastisitas}

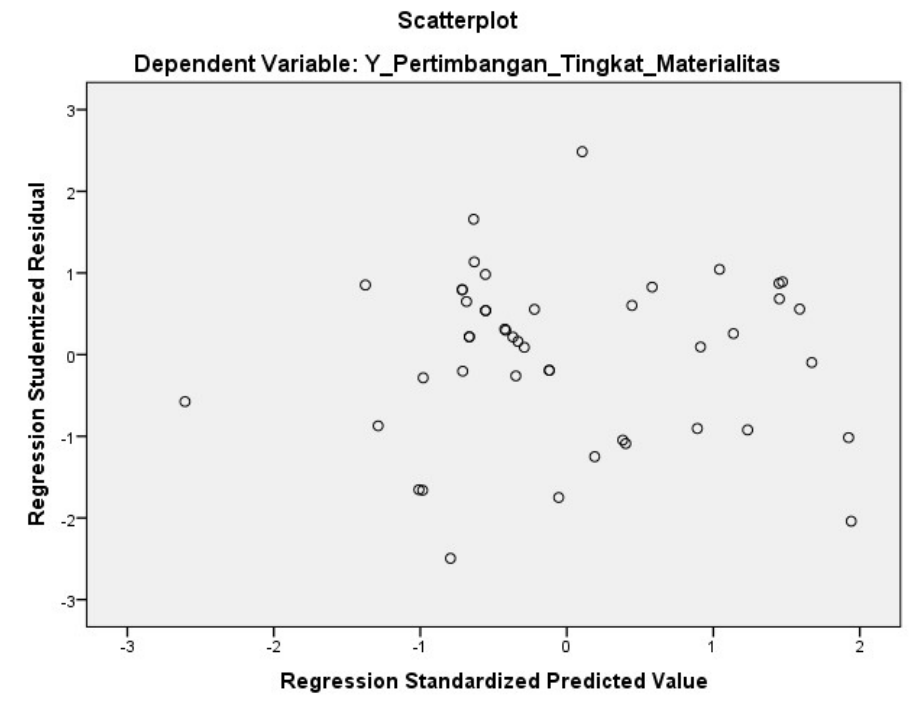

Dari output di atas dapat diketahui bahwa titik-titik tidak membentuk pola yang jelas, dan titik-titik menyebar di atas dan di bawah angka 0 pada sumbu Y. Jadi dapat disimpulkan bahwa tidak terjadi heterokedastisitas dalam model regresi.

\subsection{Hasil uji t (Parsial)}

\begin{tabular}{|c|c|c|c|c|c|}
\hline \multirow[b]{2}{*}{ Model } & \multicolumn{2}{|c|}{$\begin{array}{c}\text { Unstandardized } \\
\text { Coefficients }\end{array}$} & \multirow{2}{*}{$\begin{array}{c}\text { Standardized } \\
\text { Coefficients } \\
\text { Beta } \\
\end{array}$} & \multirow[b]{2}{*}{$\mathrm{T}$} & \multirow[b]{2}{*}{ Sig. } \\
\hline & $\mathrm{B}$ & Std. Error & & & \\
\hline 1 (Constant) & 35,629 & 55,841 & & 638 &, 527 \\
\hline X1_Profesionalisme & ,248 & 082 & 320 & 3,014 & ,004 \\
\hline $\begin{array}{l}\text { X2_Pengetahuan_Mendetek } \\
\text { si_Kekeliruan }\end{array}$ & ,053, & ,037 & ,116 & 1,411 & 166, \\
\hline X3_Etika Profesi & ,469 & ,084 & ,581 & 5,568 &, 000 \\
\hline
\end{tabular}

a. Dependent Variable: Y_Pertimbangan_Tingkat_Materialitas 
Berdasarkan hasil pengujian secara parsial terhadap variabel independent, menunjukan bahwa dari ke 3 variabel terdapat 2 variabel yang memiliki tingkat signifikansi dibawah 0.05 , yaitu profesionalisme dan etika profesi. Karena hasil $t_{\text {hitung }}>t_{\text {tabel }}$ dan sig $<0.05$ maka Ho ditolak dan Ha diterima, artinya bahwa profesionalisme auditor dan etika profesi memiliki pengaruh signifikan terhadap pertimbangan tingkat materialitas.

\subsection{Hasil uji F (Simultan)}

\begin{tabular}{|l|r|r|r|c|r|}
\hline Model & Sum of Squares & Df & Mean Square & F & \multicolumn{1}{c|}{ Sig. } \\
\hline 1 Regression & 174131,864 & 3 & 58043,955 & 38,731 &, $000^{\mathrm{b}}$ \\
Residual & 62942,241 & 42 & 1498,625 & & \\
Total & 237074,106 & 45 & & & \\
\hline
\end{tabular}

a. Dependent Variable: Y_Pertimbangan_Tingkat_Materialitas

b. Predictors: (Constant), X3_Etika_Profesi,

X2_Pengetahuan_Mendeteksi_Kekeliruan, X1_Profesionalisme

Berdasarkan output hasil pengujian SPSS 22 dapat disimpulkan bahwa hasil $\mathrm{F}_{\text {hitung }}$ sebesar 38.731 dengan tingkat tingkat signifikansi 0.000 , artinya $F_{\text {hitung }}>F_{\text {tabel }}(38.731>2.83)$, dengan demikian Ho ditolak dan Ha diterima.

\subsection{Koefisien Determinasi}

\begin{tabular}{|l|r|r|r|c|}
\hline & & & \multicolumn{4}{|c|}{ Model Summary } \\
Model & $\mathrm{R}$ & $\mathrm{R}$ Square & $\begin{array}{c}\text { Adjusted } \mathrm{R} \\
\text { Square }\end{array}$ & $\begin{array}{c}\text { Std. Error of the } \\
\text { Estimate }\end{array}$ \\
\hline 1 &, $857^{\mathrm{a}}$ &, 735 &, 716 & 38,71208 \\
\hline
\end{tabular}
a. Predictors: (Constant), X3_Etika_Profesi,
X2_Pengetahuan_Mendeteksi_Kekeliruan, X1_Profesionalisme
b. Dependent Variable: Y_Pertimbangan_Tingkat_Materialitas

Dari tabel di atas dapat diketahui pengaruh profesionalisme auditor, pengetahuan mendeteksi kekeliruan dan etika profesi berpengaruh signifikan terhadap pertimbangan tingkat materialitas akuntan publik sebesar $73.5 \%$, sedangkan sisanya sebesar $26.5 \%$ dipengaruhi oleh faktor lain di luar model penelitian.

\subsection{Persamaan Regresi}

\begin{tabular}{|c|c|c|c|c|c|}
\hline \multicolumn{6}{|c|}{ Coefficients $^{a}$} \\
\hline \multirow[b]{2}{*}{ Model } & \multicolumn{2}{|c|}{$\begin{array}{c}\text { Unstandardized } \\
\text { Coefficients }\end{array}$} & \multirow{2}{*}{$\begin{array}{c}\text { Standardized } \\
\text { Coefficients } \\
\text { Beta } \\
\end{array}$} & \multirow[b]{2}{*}{$\mathrm{t}$} & \multirow[b]{2}{*}{ Sig. } \\
\hline & $\mathrm{B}$ & Std. Error & & & \\
\hline 1 (Constant) & 35,629 & 55,841 & & ,638 &, 527 \\
\hline X1_Profesionalisme & ,248 & ,082 & ,320 & 3,014 & ,004 \\
\hline $\begin{array}{l}\text { X2_Pengetahuan_Mendetek } \\
\text { si_Kekeliruan }\end{array}$ & 053 & ,037 & , 116 & 1,411 & , 166 \\
\hline
\end{tabular}


a. Dependent Variable: Y_Pertimbangan_Tingkat_Materialitas

Berdasarkan Hasil pada tabel koefisien tersebut, maka dapat disusun persamaan regresi sebagai berikut :

$$
\mathrm{Y}=35.629+0.320 \mathrm{X}_{1}+0.116 \mathrm{X}_{2}+0.581 \mathrm{X}_{3}+\mathrm{e}
$$

Persamaan diatas dapat dijelaskan sebagai berikut :

1. Konstanta sebesar 35.629 artinya, jika profesionalisme auditor $\left(\mathrm{X}_{1}\right)$, mendeteksi kekeliruan $\left(\mathrm{X}_{2}\right)$ dan etika profesi $\left(\mathrm{X}_{3}\right)$ nilainya 0 maka pertimbangan tingkat materialitas (Y) sebesar 35.629.

2. Nilai koefisiensi regresi variabel profesionalisme auditor $\left(\mathrm{X}_{1}\right)$ bernilai positif, yaitu sebesar 0.320 ini dapat diartikan bahwa setiap peningkatan profesionalisme auditor sebesar 1, maka pertimbangan tingkat materialitas juga akan meningkat sebesar 0.320 .

3. Nilai koefisien regresi variabel pengetahuan mendeteksi kekeliruan $\left(\mathrm{X}_{2}\right)$ bernilai positif, yaitu sebesar 0.116 ini dapat diartikan bahwa setiap peningkatan pengetahuan mendeteksi kekeliruan sebesar 1, maka pertimbangan tingkat materialitas juga akan meningkat sebesar 0.116 .

4. Nilai koefisien regresi variabel etika profesi $\left(\mathrm{X}_{3}\right)$ bernilai positif, yaitu sebesar $0.581 \mathrm{ini}$ dapat diartikan bahwa setiap peningkatan etika profesi sebesar 1, maka pertimbangan tingkat materialitas juga akan meningkat sebesar 0.581 .

\section{KESIMPULAN}

Dari hasil pengujian dan analisis yang telah dilakukan, diperoleh kesimpulan sebagai berikut :

1. Profesionalisme, pengetahuan mendeteksi kekeliruan dan etika dapat digunakan untuk menguji besarnya pengaruh terhadap pertimbangan tingkat materialitas akuntan publik.

2. Besarnya pengaruh profesionalisme, pengetahuan mendeteksi kekeliruan, dan etika profesi adalah sebesar $38.7 \%$ terhadap pertimbangan tingkat materialitas, sedangkan $61.3 \%$ dipengaruhi oleh faktor-faktor lain diluar model penelitian ini, antara lain kompetensi, indenpendensi, objektivitas, pelatihan, struktur audit, dan lain sebagainya yang juga turut mempengaruhi pertimbangan tingkat materialitas.

3. Secara parsial, profesionalisme dan etika profesi memiliki pengaruh yang signifikan terhadap pertimbangan tingkat materialitas akuntan publik. 


\section{DAFTAR PUSTAKA}

Abdul Halim. 2008. Auditing 1 Dasar-dasar Audit Laporan Keuangan.Yogyakarta : UPP AMP YKPN.

Agoes, Sukrisno. (2012). Auditing Petunjuk Praktis Pemeriksaan Akuntan oleh Kantor Akuntan Publik. Edisi Keempat. Buku I. Jakarta: Salemba Empat.

Arens, Alvin A, Randal J. Elder, dan Mark S. Beasley. (2012). Auditing and Assurance Services; An Integrated Approach. Fourteen Edition. New Jersey: Pearson Education Inc.

Febrianty. (2012). "Pengaruh Profesionalisme Auditor Terhadap Pertimbangan Tingkat Materialitas Audit atas Laporan Keuangan", Jurnal Ekonomi dan Informasi Akuntansi (JENIUS). Vol.2 No.2. pp. 159-200.

Ghozali, Imam. (2011). Aplikasi Analisis Multivariate dengan Program IBM SPSS 19. Edisi Kelima. Semarang: Badan Penerbit Universitas Diponegoro.

Herawaty, Arleen dan Yulius Kurnia Susanto. (2009). "Pengaruh Profesionalisme, Pengetahuan Mendeteksi Kekeliruan, dan Etika Profesi Terhadap Pertimbangan Tingkat Materialitas Akuntan Publik", JAAI. Vol. 13 No. 2. pp. 211-220. 